\title{
A Possible Relationship Between Polymorphisms of Glutathione S-Transferase M1, P1 and T1 Genes and Rheumatoid Arthritis in Zahedan, Southeast Iran
}

\author{
Güneydoğu İran Zahedan'da Glutation S-Transferaz M1, P1 ve T1 Genlerinin \\ Polimorfizmleri ve Romatoid Artrit Arasındaki Muhtemel İlişki \\ Mohammad HASHEMI, ${ }^{1,2}$ Ebrahim ESKANDARI-NASAB, ${ }^{1}$ Zahra ZAKERI, ${ }^{2}$ Mahdi ATABAKI, ${ }^{3}$ \\ Hamzeh REZAEI, ${ }^{1}$ Gholamreza BAHARI, ${ }^{1}$ Mohsen TAHERI ${ }^{4}$ \\ ${ }^{1}$ Cellular and Molecular Research Center, Zahedan University of Medical Sciences, Zahedan, Iran \\ ${ }^{2}$ Department of Internal Medicine, Zahedan University of Medical Sciences, Zahedan, Iran \\ ${ }^{3}$ Department of Immunology, Zahedan University of Medical Sciences, Zahedan, Iran \\ ${ }^{4}$ Genetic of Non-Communicable Disease Research Center, Zahedan University of Medical Sciences, Zahedan, Iran
}

\begin{abstract}
Objectives: This study aims to investigate the possible relationship between glutathione S-transferase (GST) gene (GSTM1, GSTT1, and GSTP1) polymorphisms and susceptibility to rheumatoid arthritis (RA).
\end{abstract}

Patients and methods: This case-control study was conducted on 100 Iranian patients with RA (88 females, 12 males; mean age $44.1 \pm 13.2$ years; range 17 to 75 years) and 100 healthy subjects ( 68 females and 32 males; mean age $45.7 \pm 9.6$ years; range 23 to 70 years). The GSTP1 polymorphism was determined using a tetra amplification refractory mutation system-polymerase chain reaction (Tetra-ARMS-PCR) assay, whereas the GSTM1 and GSTT1 polymorphisms were analyzed by multiplex PCR.

Results: The null genotype of GSTM1 was significantly higher in the patients with RA $(78.0 \%)$ than in the control group $(59.0 \%)$, and there was a risk factor for susceptibility to $\mathrm{RA}(\mathrm{OR}=2.86,95 \% \mathrm{Cl}=1.45-5.66, \mathrm{p}=0.002)$. However, no significant difference was observed in the null genotype of GSTT1 among RA patients and healthy subjects (19\% and $11 \%$, respectively). There was no difference in the frequency distribution of the GSTP1 lle105Val polymorphism between the groups (chi-square=1.69, $p=0.429$ ).

Conclusion: Our findings showed that only the GSTM1 genetic polymorphism is associated with RA risk in a sample of the Iranian population.

Key words: Glutathione S-transferase; polymorphism; rheumatoid arthritis.
Amaç: Bu çalışmada glutation S-transferaz (GST) gen (GSTM1, GSTT1 ve GSTP1) polimorfizmi ve romatoid artrit (RA) yatkınlığı arasındaki ilişkinin araştıııması amaçlandı.

Hastalar ve yöntemler: Bu olgu kontrollü çalışmaya İranlı 100 RA hastası (88 kadın, 12 erkek; ort. yaş $44.1 \pm 13.2$ yıl; dağılım 17-75 yıl) ve 100 sağlıklı birey (68 kadın ve 32 erkek, ort. yaş $45.7 \pm 9.6$ yıl; dağılım 23-70 yıl) dahil edildi. GSTP1 polimorfizm tetra amplifikasyona dirençli mutasyon sistem polimeraz zincir reaksiyonu (Tetra-ARMS-PCR) ile belirlenirken, GSTM1 ve GSTT1 polimorfizmleri multipleks PCR kullanılarak analiz edildi.

Bulgular: GSTM1'in sıfır genotipi, kontrol grubuna kıyasla (\%59.0), RA'lı hasta grubunda (\%78.0) anlamlı düzeyde daha yüksek olup, RA yatkınlığı için bir risk faktörüydü (OR=2.86, \%95 GA=1.45-5.66, $\mathrm{p}=0.002$ ). Bununla birlikte, RA'ı hastalar ve sağlıklı kişiler arasında GSTT1'in sıfır genotipi açısından anlamlı bir farka rastlanmadı (sırasıyla $\% 19$ ve \%11). GSTP1 lle105Val polimorfizminin sıklık dağııımı gruplar arasında farklı değildi (ki-kare=1.69, $\mathrm{p}=0.429$ ).

Sonuç: Bulgularımız yalnızca GSTM1 genetik polimorfizminin İranlı bir nüfus örnekleminde RA riski ile ilişkili olduğunu göstermiştir.

Anahtar sözcükler: Glutation S-transferaz; polimorfizm; romatoid artrit.

\footnotetext{
Received: July 2, 2012 Accepted: September 10, 2012

Correspondence: Mohammad Hashemi, Ph.D. Department of Clinical Biochemistry, Zahedan University of Medical Sciences, 98135 Zahedan, Iran Tel: +98 5413414571 e-mail: mhd.hashemi@gmail.com 
Rheumatoid arthritis (RA) is a chronic, systemic autoimmune disease of unknown etiology. Both genetic and environmental factors have been shown to be relevant, contributory factors to the expression and complications of this disease. ${ }^{[1,2]}$ The prevalence of RA is about $1 \%$ of the total population, and genetic factors have been estimated to account for $60 \%$ of the disease risk. ${ }^{[3]}$ Glutathione S-transferase (GST) genes, known as a superfamily of phase II metabolic enzymes, catalyze the detoxification of xenobiotics via glutathione conjugation. They are also believed to play an important role in detoxifying products generated by the activity of reactive oxygen species (ROS). The glutathione S-transferase Mu 1 (GSTM1), glutathione S-transferase P 1 (GSTP1), and glutathione S-transferase theta 1 (GSTT1) genes are mapped on chromosome 1 (1p13.3), chromosome 11 (11q13), and chromosome 22 (22q11.2), respectively. ${ }^{[4]}$ There is evidence that some allelic variants are associated with differences in detoxification efficiency. In addition, these three genes have been shown to have functional polymorphisms that are frequently present in the general population. ${ }^{[5]}$ Individuals with homozygous deletions at the M1 and T1 loci of GST (GSTM1 null and GSTT1 null, respectively) have no functional enzymatic activity. Deletions in the GSTM1 and GSTT1 genes occur with varying frequencies in different populations. It has been reported that a one point mutation in the coding region of the GSTP1 gene results in the substitution of isoleucine (Ile) for valine (Val) at codon 105, which modifies the enzyme activity. ${ }^{[6,7]}$ Glutathione S-transferases have peroxidase activity concerning cytotoxic metabolites that are produced in inflammatory reactions, and this is the main feature of RA. In addition, it has been proposed that defense mechanisms against ROS are impaired in RA.

Though there are several studies regarding the association between GSTs polymorphisms and the risk of RA, the findings are controversial. Therefore, the aim of the present study was to evaluate the impact of GSTs polymorphisms on the susceptibility to RA in a sample of Iranian population.

\section{PATIENTS AND METHODS}

This case-control study was performed from October 2010 to March 2012 in Clinic of Rheumatology, Ali-Ebneh Abitaleb hospital Zahedan, Iran. We investigated the possible association between the GSTM1, GSTT1, GSTP1 polymorphisms of GSTs genes and RA susceptibility in 100 patients (88 females and 12 males; mean age $44.1 \pm 13.2$ years; range 17 to 75 years) who fulfilled the American College of Rheumatology (ACR) criteria for RA. ${ }^{[8]}$ All the subjects were patients of the Rheumatology Clinic at Zahedan University of Medical Sciences. ${ }^{[2,9,10]}$ The control group consisted of 100 healthy individuals (68 females and 32 males; mean age $45.7 \pm 9.6$ years; range 23 to 70 years) who were unrelated to the RA patients. The ethics committee of the university approved the project, and informed consent was obtained from all patients and healthy individuals. Blood samples from the patients and healthy controls were collected in ethylenedinitrilotetraacetic acid disodium salt (EDTA-Na) tubes. Genomic DNA was then extracted from the peripheral blood samples that had been collected in the tubes containing EDTA in a manner that has been previously described. ${ }^{[10]}$

\section{The GSTM1 and GSTT1 gene polymorphisms}

Examinations of the GSTM1 and GSTT1 gene polymorphisms were performed using multiplex polymerase chain reaction (PCR), with the TLR2 gene as an internal control, as described by Hashemi et al. ${ }^{[1]}$

The primers used were 5'-GCTGCCCTACTTGATTGATG-3' (sense) and $5{ }^{\prime}$-CCCCAAATCCAAACTCTGTC-3`(anti-sense) for the GSTM1 gene, resulting in a 325-bp fragment; 5'-TTCTGCTTTATGGTGGGGTC-3' (sense) and 5'-GTGATGTTCCCTGTTTTCCT-3' (anti-sense) for the GSTT1 gene, resulting in a 542-bp fragment, and 5'-GATGCATTTGTTTCTTACAGTGAGCG-3’ (sense) and 5'-GTGATGTTCCCTGTTTTCCT-3'(anti-sense) for the TLR2 gene, resulting in a 259-bp fragment. The GSTM1 null and GSTT1 null variant forms were defined by the absence of the 325- and 542-bp fragments, respectively.

\section{The GSTP1 polymorphism}

The GSTP1 polymorphism was determined by a tetra-primer amplification refractory mutation system PCR (T-ARMS-PCR) as described in an earlier study. ${ }^{[1]}$ Two external primers (forward outer: 5'-CAGGTGT CAGGTGAGCTCTGAGCACC-3' and reverse outer: 5'-ATAAGGGTGCAGGTTGTGTCTTGTCCCA-3') and two internal primers [forward inner (A allele or Ile allele): 5'-CGTGGAGGACCTCCGCTGCAAATC CA-3' and reverse inner (G allele or Val allele): 5 '-GCT CACATAGTTGGTGTAGATGAGGGATAC-3'] were used for detection of the GSTP1 polymorphism. The product sizes were 233-bp for the A allele, 290-bp for the $\mathrm{G}$ allele, and 467-bp for the outer primers (control band). 


\section{Statistical analysis}

Statistical analysis was performed using the Statistical Package for the Social Sciences (SPSS Inc., Chicago, Illinois, USA) version 18.0 software program for Windows. The associations between the genotype of the GSTs gene and RA were assessed by computing the odds ratio (OR) and 95\% confidence intervals ( $95 \%$ CI) by logistic regression analyses.

\section{RESULTS}

The frequency distribution of the GSTM1, GSTT1, and GSTP1 genotypes was compared between 100 RA patients and 100 normal subjects (Table 1). The null genotype of GSTM1 was more prevalent in the patients (78.0\%) than in the controls (59.0\%), which resulted in a significant association between the incidence of RA and the GSTM1 null genotype $(\mathrm{OR}=2.86$; 95\% CI=1.54-5.66; $\mathrm{p}=0.002$ ). However, no significant difference was observed among the groups regarding the null genotype of GSTT1 (19\% versus 11\%). The GSTT1 null did not increase the risk of RA $(\mathrm{OR}=1.85$; 95\% CI=0.78-4.38; $\mathrm{p}=0.165)$. In addition, the results showed that the genotypic and allelic frequencies of GSTP1 did not differ significantly between the RA patients and the control subjects (chi-square $=1.69$; $\mathrm{p}=0.429$ and chi-square $=0.57 ; \mathrm{p}=0.450$, respectively).

\section{DISCUSSION}

In the present study, we evaluated the association of the GSTM1, GSTT1, and GSTP1 genotypes and the susceptibility to RA in a sample of Iranian population. The findings imply that the GSTM1 null genotype was significantly associated with the risk of RA, though no association was seen between the GSTT1 null genotype and GSTP1 Ile105Val genotypes when examining vulnerability to RA.

In agreement with our findings, Yun et al. ${ }^{[12]}$ reported that the null polymorphism of GSTM1, but not the GSTT1 or GSTP1 genotypes, is associated with an increased risk for RA, but Keenan et al. ${ }^{[13]}$ found no significant differences in the distributions of the GSTP1, GSTT1 and GSTM1 genotypes between RA and healthy subjects. In contrast, Bohanec et al. ${ }^{[14]}$ provided evidence that patients with the GSTT1 null genotype had a higher risk for developing high activity RA than patients with GSTT1 genes present and that the GSTM1 and GSTP1 polymorphisms were not associated with the disease activity.

Glutathione S-transferases, the multifunctional enzymes, promote the detoxification of a wide range of xenobiotics, such as environmental carcinogens, steroids, and ROS. The most common substrates for GSTs are ROS compounds, which are products of oxidative stress (OS). ${ }^{[15]}$ It is well known that individuals with the GSTM1 null or GSTT1 null genotypes display an absence of enzymatic activity and are thought to be at an elevated risk for the cytotoxic effects of a wide spectrum of carcinogens and xenobiotics. ${ }^{[16,17]}$ In addition, it has been demonstrated that the GSTP1 Ile105Val polymorphism is associated with altered catalytic function and that GSTP1 malfunction makes cells vulnerable to oxidative DNA damage. ${ }^{[18,19]}$ Given that the GSTM1 and GSTT1 null genotypes along with the GSTP1Ile105Val polymorphism display decreased

\begin{tabular}{|c|c|c|c|c|c|c|c|c|c|c|}
\hline \multirow[t]{2}{*}{ GST genotypes } & \multicolumn{2}{|c|}{ Patients } & \multicolumn{2}{|c|}{ Control } & \multicolumn{2}{|c|}{ OR (95\% CI) } & \multirow[t]{2}{*}{$p$} & \multicolumn{2}{|c|}{${ }^{\star} \mathrm{OR}(95 \% \mathrm{CI})$} & \multirow[t]{2}{*}{$p$} \\
\hline & $\mathrm{n}$ & $\%$ & $\mathrm{n}$ & $\%$ & Mean & Range & & Mean & Range & \\
\hline \multicolumn{11}{|l|}{ GSTM1 } \\
\hline Wild & 22 & 22.0 & 41 & 41.0 & \multicolumn{2}{|c|}{ Reference } & - & \multicolumn{2}{|c|}{ Reference } & - \\
\hline Null & 78 & 78.0 & 59 & 59.0 & 2.46 & $1.33-4.57$ & 0.004 & 2.86 & $1.45-5.66$ & 0.002 \\
\hline \multicolumn{11}{|l|}{ GSTT1 } \\
\hline Wild & 81 & 81.0 & 89 & 89.0 & \multicolumn{2}{|c|}{ Reference } & - & \multicolumn{2}{|c|}{ Reference } & - \\
\hline Null & 19 & 19.0 & 11 & 11.0 & 1.90 & $0.85-4.23$ & 0.117 & 1.85 & $0.78-4.38$ & 0.165 \\
\hline \multicolumn{11}{|l|}{ GSTP1 } \\
\hline AA (Ile/Ile) & 52 & 52.0 & 44 & 44.0 & \multicolumn{2}{|c|}{ Reference } & - & \multicolumn{2}{|c|}{ Reference } & - \\
\hline AG (Ile/Val) & 37 & 37.0 & 46 & 34.0 & 0.68 & $0.37-1.23$ & 0.201 & 0.68 & $0.36-1.28$ & 0.234 \\
\hline GG (Val/Val) & 11 & 11.0 & 10 & 10.0 & 0.93 & $0.36-2.39$ & 0.882 & 0.73 & $0.27-2.02$ & 0.549 \\
\hline \multicolumn{11}{|l|}{ GSTP1 allele } \\
\hline A allele (Ile allele) & 141 & 70.5 & 134 & 67.0 & \multicolumn{2}{|c|}{ Reference } & - & & & \\
\hline G allele (Val allele) & 59 & 29.5 & 66 & 33.0 & 1.17 & $0.77-1.79$ & 0.517 & & & \\
\hline
\end{tabular}


GST detoxification, they are thought to be potential risk factors that influence susceptibility to RA and impact the outcome of this disease. ${ }^{[12]}$

It has been reported that the risk of developing severe RA disease is increased in female patients who smoke that also have the GSTM1 null polymorphism compared with nonsmoking RA patients with the same genotype. ${ }^{[20]}$ Increased severity in RA has been shown to be associated with a null polymorphism of GSTM1. ${ }^{[21]}$ Furthermore, it has been demonstrated that in both Caucasian and South Asian populations, the GSTT1 null genotype, but not the GSTM1, is associated with RA. ${ }^{[1]}$

Overall, although some smallstudies haveexamined the relationship between the polymorphisms of GSTs and the risk of RA, the association still remains unclear, and the debate continues. The reason for the controversial results of these studies could be associated with the differences in the populations studied and their exposures to agents related to RA development. Our findings suggest that the GSTM1 null genotype is a risk factor for susceptibility to RA in a sample of Iranian population. However, this needs to be confirmed by other large studies involving RA.

\section{Declaration of conflicting interests}

The authors declared no conflicts of interest with respect to the authorship and/or publication of this article.

\section{Funding}

This work was supported by a research grant from Zahedan University of Medical Sciences. We thank all subjects who willingly participated in the study.

\section{REFERENCES}

1. Ghelani AM, Samanta A, Jones AC, Mastana SS. Association analysis of TNFR2, VDR, A2M, GSTT1, GSTM1, and ACE genes with rheumatoid arthritis in South Asians and Caucasians of East Midlands in the United Kingdom. Rheumatol Int 2011;31:1355-61.

2. Hashemi M, Moazeni-Roodi AK, Fazaeli A, Sandoughi M, Taheri M, Bardestani GR, et al. The L55M polymorphism of paraoxonase-1 is a risk factor for rheumatoid arthritis. Genet Mol Res 2010;9:1735-41.

3. Turesson C, Matteson EL. Genetics of rheumatoid arthritis. Mayo Clin Proc 2006;81:94-101.

4. Mitrunen K, Jourenkova N, Kataja V, Eskelinen M, Kosma VM, Benhamou S, et al. Glutathione S-transferase M1, M3, P1, and T1 genetic polymorphisms and susceptibility to breast cancer. Cancer Epidemiol Biomarkers Prev 2001;10:229-36.
5. Safarinejad MR, Shafiei N, Safarinejad S. The association of glutathione-S-transferase gene polymorphisms (GSTM1, GSTT1, GSTP1) with idiopathic male infertility. J Hum Genet 2010;55:565-70.

6. Ramos DL, Gaspar JF, Pingarilho M, Gil OM, Fernandes AS, Rueff J, et al. Genotoxic effects of doxorubicin in cultured human lymphocytes with different glutathione S-transferase genotypes. Mutat Res 2011;724:28-34.

7. Vogl FD, Taioli E, Maugard C, Zheng W, Pinto LF, Ambrosone C, et al. Glutathione S-transferases M1, T1, and P1 and breast cancer: a pooled analysis. Cancer Epidemiol Biomarkers Prev 2004;13:1473-9.

8. Arnett FC, Edworthy SM, Bloch DA, McShane DJ, Fries JF, Cooper NS, et al. The American Rheumatism Association 1987 revised criteria for the classification of rheumatoid arthritis. Arthritis Rheum 1988;31:315-24.

9. Sandoughi M, Fazaeli A, Bardestani G, Hashemi M. Frequency of HLA-DRB1 alleles in rheumatoid arthritis patients in Zahedan, southeast Iran. Ann Saudi Med 2011;31:171-3.

10. Hashemi M, Moazeni-Roodi AK, Fazaeli A, Sandoughi M, Bardestani GR, Kordi-Tamandani DM, et al. Lack of association between paraoxonase-1 Q192R polymorphism and rheumatoid arthritis in southeast Iran. Genet Mol Res 2010;9:333-9.

11. Hashemi M, Eskandari-Nasab E, Fazaeli A, Bahari A, Hashemzehi NA, Shafieipour S, et al. Association of genetic polymorphisms of glutathione-S-transferase genes (GSTT1, GSTM1, and GSTP1) and susceptibility to nonalcoholic fatty liver disease in Zahedan, Southeast Iran. DNA Cell Biol 2012;31:672-7.

12. Yun BR, El-Sohemy A, Cornelis MC, Bae SC. Glutathione S-transferase M1, T1, and P1 genotypes and rheumatoid arthritis. J Rheumatol 2005;32:992-7.

13. Keenan BT, Chibnik LB, Cui J, Ding B, Padyukov L, Kallberg $\mathrm{H}$, et al. Effect of interactions of glutathione S-transferase T1, M1, and P1 and HMOX1 gene promoter polymorphisms with heavy smoking on the risk of rheumatoid arthritis. Arthritis Rheum 2010;62:3196-210. doi: 10.1002/art.27639.

14. Bohanec Grabar P, Logar D, Tomsic M, Rozman B, Dolzan V. Genetic polymorphisms of glutathione S-transferases and disease activity of rheumatoid arthritis. Clin Exp Rheumatol 2009;27:229-36.

15. Whalen R, Boyer TD. Human glutathione S-transferases. Semin Liver Dis 1998;18:345-58.

16. Seidegård J, Vorachek WR, Pero RW, Pearson WR. Hereditary differences in the expression of the human glutathione transferase active on trans-stilbene oxide are due to a gene deletion. Proc Natl Acad Sci U S A 1988;85:7293-7.

17. Bolt HM, Thier R. Relevance of the deletion polymorphisms of the glutathione S-transferases GSTT1 and GSTM1 in pharmacology and toxicology. Curr Drug Metab 2006;7:613-28. 
18. Watson MA, Stewart RK, Smith GB, Massey TE, Bell DA. Human glutathione S-transferase P1 polymorphisms: relationship to lung tissue enzyme activity and population frequency distribution. Carcinogenesis 1998;19:275-80.

19. Cote ML, Chen W, Smith DW, Benhamou S, Bouchardy C, Butkiewicz D, et al. Meta- and pooled analysis of GSTP1 polymorphism and lung cancer: a HuGE-GSEC review. Am J Epidemiol 2009;169:802-14.
20. Mattey DL, Hutchinson D, Dawes PT, Nixon NB, Clarke S, Fisher J, et al. Smoking and disease severity in rheumatoid arthritis: association with polymorphism at the glutathione S-transferase M1 locus. Arthritis Rheum 2002;46:640-6.

21. Mattey DL, Hassell AB, Plant M, Dawes PT, Ollier WR, Jones PW, et al. Association of polymorphism in glutathione S-transferase loci with susceptibility and outcome in rheumatoid arthritis: comparison with the shared epitope. Ann Rheum Dis 1999;58:164-8. 